Vol 6 No 1 February 2021

FARMATERA

E-ISSN: 2528-410X

CASE REPORT

\title{
Case Report: Preoperative Hormone Replacement Therapy in Hypocortisol and Hypothyroid Patients with Residual Pituitary Adenoma Tumors
}

\author{
Huwainan Nisa Nasution ${ }^{1}$, Sony Wibisono Mudjanarko² \\ ${ }^{1}$ Department of Internal Medicine, Faculty of Medicine, University of Muhammadiyah Sumatera Utara, \\ ${ }^{2}$ Department of Internal Medicine, Faculty of Medicine, University of Airlangga \\ Correspondence Email: huwainannisa@umsu.ac.id
}

\begin{abstract}
Pituitary tumors are benign tumors that occur in the pituitary gland with a presentation of $10 \%$ of all intracranial tumors. If the size of the tumor is $\quad>1 \mathrm{~cm}$, the pituitary tumor is called a macroadenoma, the large size will have a mass effect so that there is an emphasis on the tumor area and its surroundings. This emphasis will manifest in hyposecretion of the hormones produced in the pituitary. We report a case of 57-year-old male with complaints of decreased vision since 3.5 months. The patient had previously been diagnosed with a pituitary tumor 6 years ago and had surgery. After diagnostic steps, the patient is diagnosed with a residual pituitary adenoma tumor with hypocortisol and hypothyroidism. Hormone replacement therapy was performed by administering methilprednisolone tablets $16 \mathrm{mg}-0-8 \mathrm{mg}$ and levothyroxine tablets 1 x $50 \mu \mathrm{g}$. The patient was planned to undergo an Endoscopic Endonasal Excision Tumor surgery with $125 \mathrm{mg} / 12$ hour preoperative injection of methilprednisolon. The provision of preoperative hormone replacement therapy aims to correct hormonal imbalances that can be an intraoperative complication.
\end{abstract}

Keywords: Residual pituitary adenoma tumor, hypocortisol, hypothyroidism

\section{INTRODUCTION}

Pituitary tumors are benign tumors that occur in the pituitary gland with an incidence of $10 \%$ of all intracranial tumors. ${ }^{1}$ The most common type of these tumors is the non-functional type that is not associated with hormone hypersecretion, with an incidence of 50-60\%. from pituitary tumors. $^{2}$ The pituitary is a place for regulating important hormones such as Growth Hormone $(\mathrm{GH})$, Thyroid

Buletin Farmatera

Fakultas Kedokteran (FK)

Universitas Muhammadiyah Sumatera Utara (UMSU)

http://jurnal.umsu.ac.id/index.php/buletin_farmatera
Stimulating Hormone (TSH), Adenocorticotrophic Hormone (ACTH), Prolactin, sex hormone, Anti Diuretic Hormone (ADH), Vasopressin and Oxytosin. The mass effect of the tumor will cause pressure on the tumor area and its surroundings which will result in hyposecretion of the hormones produced in the pituitary. ${ }^{1,2,3}$

In this case the patient was found to have hypocortisol and hypothyroidism

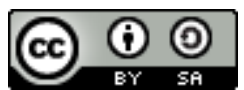


caused by pituitary tumor residif. If the patient is to be surgically excised on the pituitary tumor, this hormonal imbalance can become difficult during the operation. So it is recommended that patients who will undergo pituitary tumor excision surgery to do as much as possible hormone replacement therapy to approach its normal function. $^{4}$

\section{CASE PRESENTATION}

A man, aged 57, went to a government hospital in Surabaya with the main complaint of decreased vision since the last 3.5 months. Decreased vision is slow. The function of the left eye is felt to be decreased compared to the right. Vision is clearer when looking in the morning than at night. Previously the patient had complained about decreased visual function in 2009, then the patient underwent an examination and was diagnosed with a pituitary tumor. The patient underwent surgery in December 2009 and after the operation the patient stated that the patient's vision function had improved. Headaches, nausea and vomiting are denied. Previous history of diabetes mellitus and high blood pressure was denied by the patient. A family history of suffering from the same disease was denied by the patient.

On physical examination, the general condition is sufficient with GCS 456. Blood pressure 130/70 $\mathrm{mmHg}$, pulse 42 times / minute, regular rhythm, lifting strength, normal amplitude, breathing 21 times / minute, axillary temperature $36,70 \mathrm{C}$. Weight $72 \mathrm{~kg}$, height $165 \mathrm{~cm}$. Examination of the head and neck found surgical scars in

Buletin Farmatera

Fakultas Kedokteran (FK)

Universitas Muhammadiyah Sumatera Utara (UMSU)

http://jurnal.umsu.ac.id/index.php/buletin_farmatera the frontal region measuring $7 \mathrm{~cm} \times 1 \mathrm{~cm}$, there is an area that is sunken inward. In the eye, isochore pupils, $3 \mathrm{~mm} / 3 \mathrm{~mm}$ in size, decreased RC (+) / (+) decreased, left exotropia $(+)$, VOD: light perception $(+)$, VOS: light perception (-), secondary atrophic papilla ODS. There was no palpable enlargement of the thyroid gland, no tenderness, no bruit sound. The patient did not have enlarged lymph nodes. Other physical examinations within normal limits.

The results of the anatomical pathology examination of the tumor tissue during the operation on December 9, 2009, with the conclusion of the Pituitary Adenoma Acidophilic Type. The results of the current MRI of the head with the conclusion of a pituitary adenoma are shown in Figure 1. X-rays of the AP and lateral head with the results of a bone defect in the right temporal-parietal os, fixation wire $(+)$, good bone apposition, good sutures, normal soft tissue.

Laboratory results $\mathrm{Hb} 12.0 \mathrm{~g} / \mathrm{dl}$, HCT 34.4\%, MCV 83.3 fL, MCH 29.1 pg, MCHC 34.9 g / dL, neutrophils 46.9\%, leukocytes 6,600 / mm3, platelets 171,000 / uL, GDA $114 \mathrm{mg} / \mathrm{dL}$, total T3 $1.01 \mu \mathrm{g} / \mathrm{dL}$ (normal 0.60-1.81), total T4 $2.1 \mu \mathrm{g} / \mathrm{dL}$ (normal 4.5-10.90), FT4 $0.57 \mu \mathrm{g} / \mathrm{dL}$ (normal 0.89-1.76), Free T3 $2.58 \mathrm{pg} / \mathrm{mL}$ (normal 2.00-4, 40), TSH $2.10 \mathrm{uIU} / \mathrm{mL}$ (normal 0.35-5.5), prolactin $8.28 \mathrm{mg} / \mathrm{ml}$ (normal 2.1-17.7), cortisol $0.26 \mu \mathrm{g} / \mathrm{dL}$ (normal 4.3-22.40), growth hormone $<0.050$ $\mathrm{mg} / \mathrm{mL}$ (normal 0.050- 40). Other laboratory results such as liver, renal function, coagulation function within normal limits. The results of the AP chest X-ray are

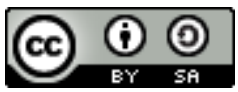


normal. Result of electrocardiogram (EKG) sinus bradycardia 43 times / minute.

The patient was diagnosed with a residive pituitary adenoma tumor with hypocortisol and hypothyroidism accompanied by II nerve atrophy and asymptomatic bradycardia. The patient was given $16 \mathrm{mg}-0-8 \mathrm{mg}$ of methylprednisolone, $1 \times 50 \mu \mathrm{g}$ of levothyroxine and $2 \times 2$ of terbutaline. Patients planned for morning cortisol examination after 5 days of treatment. After 5 days of treatment, morning cortisol was examined with a result of $1.89 \mu \mathrm{g} / \mathrm{dL}$. The patient was planned to undergo Endoscopic Endonasal Excision Tumor surgery by giving injection of methylprednisolone $125 \mathrm{mg} \mathrm{/} 12$ hours preoperatively. One day after surgery, the patient had no complaints. The morning cortisol was examined with a result of 0.19 $\mu \mathrm{g} / \mathrm{dL}$. Methylprednisolone tablet therapy $16 \mathrm{mg}-0-8 \mathrm{mg}$. Three days later, a repeat examination was performed with a cortisol result of $0.99 \mu \mathrm{g} / \mathrm{dL}$. Methylprednisolone therapy was continued and the patient was discharged for outpatient treatment.

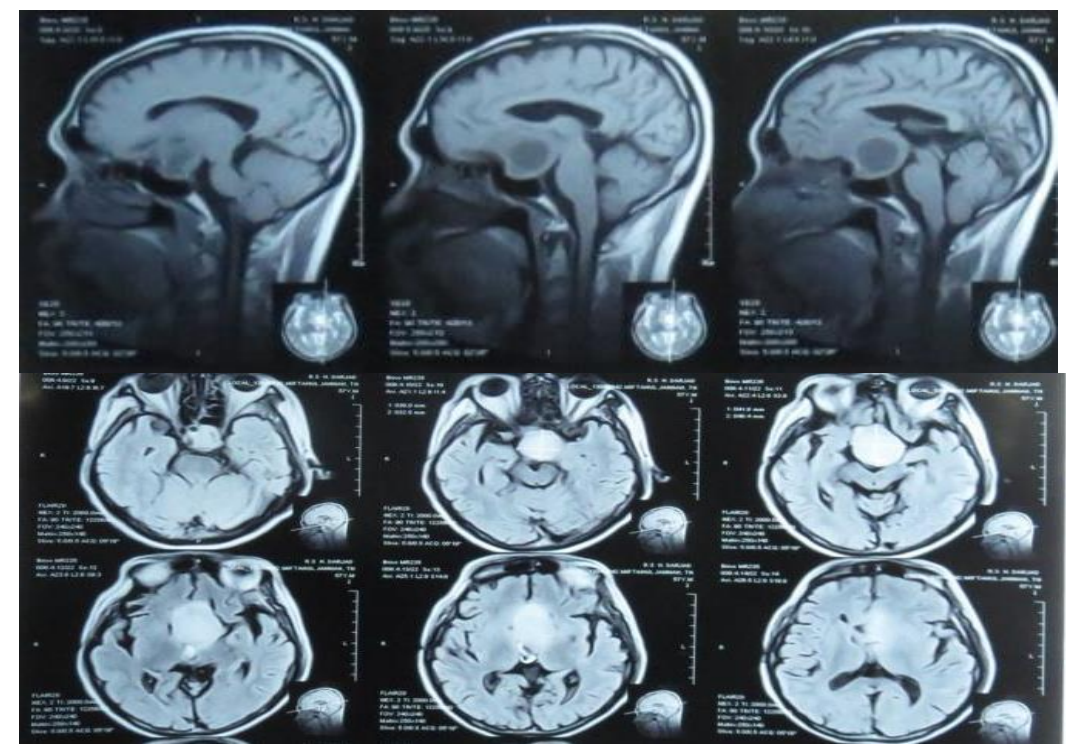

Figure 1-Head MRI

\section{DISCUSSION}

Pituitary tumors are tumors that occur in the pituitary gland with an incidence of $10 \%$ of all intracranial tumors. ${ }^{1,3}$ Epidemiologically, the incidence of pituitary tumors is estimated to be 8.214.7 cases per $100,000 .^{1,5}$ The clinical classification of pituitary tumors is

Buletin Farmatera

Fakultas Kedokteran (FK)

Universitas Muhammadiyah Sumatera Utara (UMSU)

http://jurnal.umsu.ac.id/index.php/buletin_farmatera functional (hormone-secreting tumors) and non-functional (not related to hormone hypersecretion). Immunohistochemistry and the presence of electron microscopy are the "gold standard" methods of classifying pituitary adenomas. ${ }^{1}$ Based on the size, the tumor was classified as microadenoma if the tumor diameter was $<1 \quad \mathrm{~cm}$ or

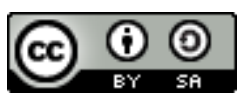


macroadenoma if the tumor diameter was $>1$ $\mathrm{cm} .{ }^{1,2,3}$ These patients were classified clinically as non-functional pituitary tumors and based on their size they were classified as macroadenomas.

The diagnosis of a pituitary tumor includes an endocrine diagnosis and an anatomical diagnosis. The initial endocrine tests are prolactin, GH, ACTH, LH, FSH, TSH, FT4, cortisol, Insulin-like Growth Factor Type 1 (IGF-1), testosterone and estradiol. ${ }^{6,7}$ After the endocrine diagnosis, the assessment of the anatomical diagnosis is carried out using X-rays of the head, CT scan of the head and MRI. ${ }^{1}$ In this patient the diagnosis of a pituitary tumor had been erect since 2009 based on clinical manifestations and a CT scan of the head. Then the clinical manifestations worsened in early 2015 , the patient was subjected to a repeat head CT scan where residive pituitary tumors were found after surgical removal of the tumor in 2009.

Treatment options for pituitary tumors include surgical therapy and nonsurgical therapy, which includes pharmacological therapy and radiation therapy. ${ }^{1,8}$ Surgery is performed if there is a progressive mass effect (usually accompanied by decreased vision) of a large macroadenoma. ${ }^{2}$ Non-surgical treatment with analgesia and hormone replacement therapy. ${ }^{1}$ Hormone replacement therapy is adjusted to the hormonal disturbances that occur in the patient. ${ }^{2}$ Pituitary insufficiency disorder usually progresses slowly due to expansion of the pituitary tumor. ${ }^{9}$ In the patient, residif pituitary tumor is found to cause more severe visual disturbances.

Buletin Farmatera

Fakultas Kedokteran (FK)

Universitas Muhammadiyah Sumatera Utara (UMSU)

http://jurnal.umsu.ac.id/index.php/buletin_farmatera
Therefore, surgery to remove the tumor was carried out again. However, prior to surgery, hormone replacement therapy should be performed prior to reoperation, namely hypocortisol and hypothyroidism.

Prior to surgery, the patient should undergo diagnostic tests to assess the function of the hypothalamic-pituitaryadrenal axis. In general, the insulin tolerance test is the gold standard for assessing the integrally of the function of the hypothalamic-pituitary-adrenal axis. ${ }^{10,11}$ Now, some endocrinologists also recommend testing $1 \mu \mathrm{g}$ ACTH 1-24 hours as the stimulation test. ${ }^{11,12}$ Patients are declared secondary hypocortisol if the results of the insulin tolerance test or the 1 $\mu \mathrm{g}$ ACTH stimulation test are lower than $500-550 \mathrm{nmol} / \mathrm{l}^{2}$ In this patient, the 24-hour insulin intolerance test and ACTH-1 cannot be tested because the test is not available, so the diagnosis of hypocortisol is based on morning cortisol results below normal values, namely on 13/4/2015 $0.26 \mu \mathrm{g} / \mathrm{dL}$ (normal 4, 3-22.40).

According to The Endocrine Society, if it is known that a patient with a pituitary tumor has hypocortisol, then the patient should be given glucocorticoid therapy before surgery. This is because hypocortisol can increase the risk during surgery. The risk that can arise is in the form of metabolic complications including increased proinflammatory cytokines and activation of the immune system. Proinflammatory cytokines such as Tumor Necrosis Factor Alpha (TNF- $\alpha$ ) and Interleukin-6 (IL-6) which will not only suppress lymphocyte function but also interfere with the signaling

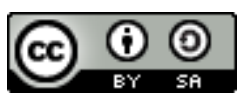


of $\mathrm{T}$ cells and inhibit the activation of Natural Killer (NK) cells. ${ }^{13}$

According to The Endocrine Society, patients with hypocortisol can be given hydrocortisone $50 \mathrm{mg}$ every 8 hours on day $0,25 \mathrm{mg}$ every 8 hours on day 1 and $25 \mathrm{mg}$ on morning day $2 .^{11}$ Then performed a perioperative follow-up examination, namely the cortisol examination at 08.00 and the ACTH 1-24 test. If the results of the examination are normal, then it is not necessary to administer perioperative glucocorticoids, only need to do a reexamination of cortisol on days 1 to 3 postoperatively. However, if the examination results are abnormal, it is necessary to give hydrocortisone or dexamethasone for 48 hours. The recommended dosage is hydrocortisone 50 mg every 8 hours on day $0,25 \mathrm{mg}$ every 8 hours on day 1 and $25 \mathrm{mg}$ at 08.00 on day $2 .^{11}$

Another recommendation states that patients with hypocortisol undergoing pituitary tumor resection surgery can be given intravenous hyrocortisone at a dose of $100 \mathrm{mg}$ before surgery and every 6 hours for 24 hours (total 5 doses). Then every day for 2 days, check the serum cortisol levels in the morning. If the result is $>10 \mu \mathrm{g} / \mathrm{dL}$ and the patient feels no complaints, then the patient can be discharged without additional steroid replacement or can also be given hydrocortisone $15 \mathrm{mg}$ in the morning and 5 $\mathrm{mg}$ in the afternoon. Long-acting glucocorticoids, prednisone, can be used as an alternative with a dose of $5 \mathrm{mg}$ in the morning and $2.5 \mathrm{mg}$ in the afternoon. However, there are some patients who get

Buletin Farmatera

Fakultas Kedokteran (FK)

Universitas Muhammadiyah Sumatera Utara (UMSU)

http://jurnal.umsu.ac.id/index.php/buletin_farmatera enough prednisone $5 \mathrm{mg}$ in the morning. Another glucocorticoid alternative that can be used is methylprednisolone which has shown satisfactory results. Methilprednisolone can be considered when hydrocortisone has reached a dose of 100 mg per day. ${ }^{14}$

For intraoperative steroid administration for major surgery hydrocortisone $100 \mathrm{mg}$ intravenously before induction of anesthesia can be given and continued with the same dose every 8 hours at least for the first 24 hours. If surgical complications do not occur postoperatively, according to The Endocrine Society, then glucocorticoids are not necessary. Furthermore, a repeat examination can be done on the 3rd to 5th day postoperatively. ${ }^{11}$ This patient was given $16 \mathrm{mg}-0-8 \mathrm{mg}$ of methylprednisolone tablets. Cortisol levels in the early morning were $0.21 \mu \mathrm{g} / \mathrm{dL}$, after 5 days, the morning cortisol was repeated again with a result of $1.89 \mu \mathrm{g} / \mathrm{dL}$. Then continued for 3 more days before the operation was performed. Intraoperatively, methylprednisolone $125 \mathrm{mg} / 12$ hours was administered intravenously.

Regarding hypothyroidism in patients with pituitary tumors, the actual effect of perioperative hypothyroidism in surgery is generally unknown. However, some have reported hypothyroidism to increase the risk of perioperative complications. Risks that may arise include the cardiovascular system leading to decreased cardiac output, increased peripheral vascular resistance and decreased blood volume; on ventilation can cause a decrease in the maximum respiratory

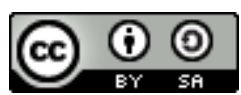


capacity thereby decreasing the diffusion capacity of carbon monooxide and weakness of the respiratory muscles; on renal function and plasma volume can cause an increase in capillary permeability, thereby triggering the displacement of fluid and albumin into the interstitial cavity, decreased renal perfusion, increased Antidiuretic Hormone (ADH), decreased Atrial Natriuretic Factor (ANF) and decreased Renin-Angiotensin Aldosterone (RAAS) system; as well as in the hemopoietic and coagulation systems can cause anemia, bleeding diathesis and prolongation of the half-life of some coagulation factors. So it is recommended that patients with hypothyroidism should be treated to near euthyroid before elective surgery. ${ }^{4}$ In general, patients receive hormone replacement therapy on the day of surgery, although this can still be an option and consideration given the half-life of $\mathrm{T} 4$ which is 6 to 7 days. However, the recommended dosage has yet to be determined. The recommended recommendation is a hypothyroid with a myxedema coma with intravenous administration of levothyroxine (LT4) 200$400 \mu \mathrm{g}$, followed by a daily dose of 50-100 $\mu \mathrm{g}$. Postoperatively, a hypothyroid patient may be considered for oral or intravenous administration of LT4. The recommended dose is $0.075-0.15 \mu \mathrm{g} / \mathrm{kg}$ body weight in a single dose. ${ }^{15}$ In this patient, because hypothyroidism is accompanied by hypocortisol, it is necessary to administer levothyroxine tablets 1 x $50 \mu \mathrm{g}$.

The prognosis in these patients is poor due to the high residive incidence of pituitary tumors, namely $60-70 \%$. This

Buletin Farmatera

Fakultas Kedokteran (FK)

Universitas Muhammadiyah Sumatera Utara (UMSU)

http://jurnal.umsu.ac.id/index.php/buletin_farmatera shows that patients who have undergone surgical removal of the tumor have a tendency for tumor regrowth. ${ }^{2}$ Then in this patient apart from suffering from a pituitary tumor is also accompanied by hormonal abnormalities, namely hypocortisol and hypothyroidism which still require further monitoring to determine whether the patient needs hormone replacement therapy in the long term or not. ${ }^{11}$

\section{CONCLUSION}

Patients with residif pituitary adenoma tumor with hypocortisol and hypothyroidism require preoperative therapy before surgery. Hormone replacement therapy is given to reach hormone levels as normal as possible prior to surgery.

\section{REFERENCES}

1. Winn H. Richard. Pituitary Tumors: Functioning and Non-fungtioning. Neurological Surgery Six Editions Chapter 134. In: Youmans, editors. Elsevier Saunders; 2011. 1476-510.

2. Ferrante E, Ferraroni M, Castrignano T, Menicatti L, Anagni M, et al. Nonfunctioning Pituitary Adenoma Database: A Useful Resource to Improve The Clinical Management of Pituitary Tumors. European Journal of Endocrinology. 2006; 155: 823-29.

3. Japardi I. Tumor Hipofisis. USU Digital Library. 2002. Available at http://repository.usu.ac.id/bitstream/123 456789/1960/1/bedahiskandar\%20japardi50.pdf.

4. Kohl BA, Schwartz S. Surgery in The Patient with Endocrine Dysfunction.

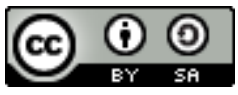


E-ISSN: 2528-410X

Endocrinology and Metabolism Clinics of North America. 2009; 93: 1031-47.

5. Bhansali A, Dutta $\mathrm{P}$, Bhat $\mathrm{MH}$, Mukherjee KK, Rajesh R, et al. Rational Use of Glucocorticoid During Pituitary Surgery-A Pilot Study. Indian Journal Medicine. 2008; 128: 294-9.

6. Heaney P. Anthony. Pituitary Tumour Pathogenesis. British Medical Bulleti 75 and 76. 2006; 81-97.

7. Vance ML. Perioperatif Management of Patients Undergoing Pituitary Surgery. Endocrinology and Metabolism Clinics of North America. 2003; 32: 355-65.

8. Stacey RJ, Powell MP. Sellar and Parasellar Tumours. Neurosurgery. Editor: Newell DW, Moore AJ. Singapore Springer. 2005; 187-97.

9. Else T, Hammer GD, Lingappa VR. Chapter 19 Penyakit Hipotalamus dan Kelenjar Hipofisis. Patofisiologi Penyakit Pengantar Menuju Kedokteran Klinis. Editors: McPhee SJ, Ferrante E et al. Non-functioning Pituitary Adenoma Database: A Useful Resource to Improve The Clinical Management of Pituitary Tumors. European Journal of Endocrinology. 2012; 155: 823-29.

10. Hana V, Jezkova J, Kosak M, Krsek M, Marek J, et al. Prediction of
Adrenocortical Insufficiency After Pituitary Adenoma Surgery Using Postoperative Basal Cortisol Levels. Physicological Research Pre-Press Article. 2010.

11. Inder WJ, Hunt PJ. Glucocorticoid Replacement in Pituitary Surgery: Guidelines for Perioperative Assesment and Management. Journal of Clinical Endocrinology and Metabolism. 2002; 87(6): 2745-50.

12. McPhee SJ. Chapter 21 Penyakit Korteks Adrenal. Patofisiologi Penyakit Pengantar Menuju Kedokteran Klinis. Editors: McPhee SJ, Ganong WF. Penerbit Buku Kedokteran EGC. 2012; 614-70.

13. Edward LD, Heyman AH, Swidan S. Hypocortisolism: An Evidence-Based Review. Integrative Medicine. 2011; 10 (4): 26-33.

14. Axelrod L. Perioperative Management of Patients Treated with Glucocorticoids. Endocrinology and Metabolism Clinics of North America. 2003; 32: 367-83.

15. Furlong K, Ahmed I, Jabbour S. Perioperative Management of Endocrine Disorders. 2008; 429-44. 